
em design

\title{
A experimentação gráfica em projetos de livros artesanais
}

The graphic experimentation

in handcrafted book's projects

\section{fauusp

\section{Julia Contreiras, Clice de Toledo Sanjar Mazzilli}

\section{CONTREIRAS, J.}

Graduada em Design pela Universidade de São Paulo

(2015), Mestre em Design pela FAU USP (2019). Atua na área de projetos gráficos, tendo participado de exposições individuais e coletivas na cidade de São Paulo.

Graduated in Design from the University of São Paulo (2015) and Master's degree in Design from FAU USP (2019). She currently acts in the area of graphic design and has participated in individual and collective exhibitions in the city of São Paulo.

\section{MAZZILLI, C. T. S.}

Professora Associada nos cursos de Arquitetura e Urbanismo e Design da Universidade de São Paulo. Orienta pesquisas em design gráfico e ambiental com ênfase em: narrativas visuais; design do livro; processos experimentais em design; espacos infantis;

Associate Professor of Architecture and Urbanism and Design at the University of São Paulo. Her research interests include both graphic and environmental design with emphasis on: visual narratives; book design; experimental design processes; children's spaces.

contato juliacontreirasagmail.com clicedusp.br
Esta pesquisa tem como objetivo explorar e analisar livros produzidos artesanalmente no Brasil do ponto de vista de projetos experimentais de designers gráficos que trabalham diretamente com técnicas manuais, como tipos móveis, serigrafia, gravura e encadernação. Para tanto, o trabalho foi dividido em duas etapas: estudo histórico e conceitual; e pesquisa prática experimental. Na primeira etapa foram realizados a revisão bibliográfica do assunto, a análise histórica e o estudo das linguagens gráficas presentes nos livros artesanais produzidos no Brasil nas décadas de 1950 a 1970. As obras analisadas foram Improvisação Gráfica de Aloísio Magalhães; $1^{\text {a }}$ Paca e Escritura de Gastão de Holanda e Cecília Jucá. Para a pesquisa prática, foram realizadas experimentações gráficas acerca da produção artesanal de livros de pequena tiragem no Laboratório de Programação Gráfica (LPG) da FAUUSP. Tais edições foram desenvolvidas a partir de material recolhido em entrevistas com profissionais do campo de publicações artesanais em São Paulo, Belo Horizonte e Rio de Janeiro. Por fim, foi analisado como, a partir da experimentação no espaço do livro, o designer articula as técnicas gráficas tradicionais com as possibilidades formais e criativas particulares a cada projeto, do ponto de vista técnico, autoral e projetual.

Palavras-chave: Design gráfico; Experimentação gráfica; Livro artesanal; Gravura; Brasil
This research seeks to explore and analyze handcrafted books produced in Brazil from the perspective of experimental projects of graphic designers who work directly with manual techniques such as movable types, screen printing, engraving and bookbinding. Therefore, the work has been divided into two parts: historical and conceptual studies; experimental practice research. In the first part, a bibliographic review of the field has been conducted, such as a historical analysis and a study of the graphic languages in the handcrafted books produced in Brazil in the 1950's and 1970's. The books analyzed were Improvisação Gráfica by Aloísio Magalhães, $1^{a}$ Paca and Escritura by Gastão de Holanda e Cecília Jucá. For the practical aspect of the research, graphic experiments were carried out on the handcrafted production of limited edition books in the Laboratory of Graphic Programming (LPG) of FAUUSP. These editions were developed with information collected through interviews with professionals from the field of handcrafted publications in São Paulo, Belo Horizonte and Rio de Janeiro. Finally, it was analyzed how, from the experimentation in the space of the book, the designer articulates the traditional graphic techniques with the formal and creative possibilities specific to each project, from the point of view of technique, author and project.

Keywords: Graphic design; Graphic experimentation; Handcrafted book; Engraving; Brazil realização

ppgdesign_fauusp
5 dezembro 2018

cidade universitária, são paulo, sp 